\title{
Experimental Investigation on the Tensile Strength of Composite Laminates Containing Open and Filled Holes
}

\author{
X. L. Fan, ${ }^{\mathrm{a}, \mathrm{b}, 1}$ W. J. Qin, ${ }^{a}$ and T. Suo ${ }^{\mathrm{b}}$ \\ a State Key Laboratory for Strength and Vibration of Mechanical Structures, School of Aerospace \\ Engineering, Xi'an Jiaotong University, Xi'an, China \\ ${ }^{\mathrm{b}}$ School of Aeronautics, Northwestern Polytechnical University, Xi'an, China \\ ${ }^{1}$ fanxueling@mail.xjtu.edu.cn
}

УДК 539.4

\section{Экспериментальное исследование предела прочности при растяжении слоистых композитов со сквозными и болтовыми отверстиями}

\author{
С. Л. Фан ${ }^{\mathrm{a}, \tilde{\sigma}, 1}$, В. Ж. Кин ${ }^{\mathrm{a}}$, Т. Суо \\ a Национальная лаборатория прочности и колебаний механических конструкций, \\ факультет авиационно-космической техники, Университет Сиань Цзяотун, Сиань, \\ Китай \\ ${ }^{\sigma}$ Факультет аэронавтики, Северо-западный политехнический университет, Сиань, Китай
}

\begin{abstract}
Экспериментально оценено влияние силь зажима, трения и размера шайбы на статические характеристики слоистых композитов со сквозными и болтовыми отверстиями. Проведено сравнение статического предела прочности при растяжении и характера разрушения слоистых композитов со сквозным и болтовым отверстиями. Результаты экспериментальных исследований показали, что на статический предел прочности при растяжении слоистых композитов влияет изначальное повреждение независимо от наличия сквозного или болтового отверстия. Сравнительный анализ результатов исследований образцов со сквозным и болтовым отверстиями подтвердил тот факт, что вид отверстия (сквозное или болтовое) незначительно влияет на усталостную прочность при растяжении исследуемьх слоистых композитов. Установлено, что такие факторы, как размер шайбы, сила зажима болта и сила трения, сущчественно влияют на предел прочности при растяжении слоистых композитов со сквозным или болтовым отверстием. Использование утолщенных шайб между слоистым материалом и болтом-заклепкой значительно увеличивает статическую прочность и долговечность слоистых композитов с болтовыми отверстиями.
\end{abstract}

Ключевые слова: предел прочности при растяжении, болтовое отверстие, сила зажима, усталость.

Introduction. It is well-known that composite laminates are sensitive to stress concentration. The most common method of assembling composite structures is by the use of mechanical fasteners, which leads to the development of stress concentration at the hole edges. The defect-induced stress concentration causea a substantial reduction in the strength of composite laminates. Therefore, prediction of strength reduction due to these locally high stress levels is of great practical interest.

A considerable scope of research data exists concerning the effect of holes on the strength of composite laminates [1-6]. An excellent summary of mechanics of mechanically fastened joints in polymer-matrix composite structures is given in works [7, 8]. Camanho and Matthews [7] gave a comprehensive review of mechanically fastened joints in 
fiber-reinforced plastics. Thoppul et al. [8] presented a thorough review of the literature including test standards, failure modes and prediction, effects of environmental conditions, time-dependent relaxation of joints, and nondestructive evaluation techniques. The mechanical behavior of a filled-hole composite laminates is different and more complicated than that of the open-hole ones. In order to numerically study the stress and failure developments of laminates containing a filled hole, several simplified models were proposed $[9,10]$. For example, Dano et al. [10] developed a progressive damage model to study the effects of failure criteria and damage model on the mechanical behavior of filled-hole composite laminates, which was implemented in the ABAQUS commercial software. While the stress and failure modes of composite laminates containing holes has been studied and reported extensively, there are few works concerning the comparative study of the effect of washer size on static and fatigue strength values of composite laminates containing holes [11-13]. There are additional effects to be considered, such as the effect of washer size, the related clamping force and friction on the strength of filled-hole composite laminates.

Since assembled composite structures are most frequently used in aircraft and aerospace components, and filled-hole tension may be a critical design consideration for composite materials, it is vital to understand the mechanical behavior of open- and filled-hole composites subjected to static tensile or cyclic tensile-tensile loading conditions. As a contribution to this need, the objective of the present paper is to experimentally study the tensile static and fatigue strength values of composite laminates containing open and filled holes.

Problem Statement. Consider a composite laminate specimen made from fiberreinforced unidirectional plies, containing a central circular hole with diameter $\mathrm{D}$, as shown in Fig. 1, where the specimen length, width, and thickness are designated as $L, W$, and $t$, respectively. Four basic ply orientation directions $\left(0,90,+45\right.$, and $\left.-45^{\circ}\right)$ are selected and indicated in Fig. 1. Open- and filled-hole tension tests of balanced symmetric laminates (with respect to the middle surface) are performed to determine the notched laminate tensile strength. In case of an open-hole tension test, no constraint is imposed on the hole. In contrast, for the filled-hole test, in order to distribute the clamp-up load, a bolt is placed into the laminate hole with two thick washers inserted between the laminate and the bolt head/tail. An in-plane tensile load $P$ is applied to the composite laminate which leads to the laminate deformation in a net-tension mode in its own plane. Failure occurs when the laminate cannot sustain any additional load.
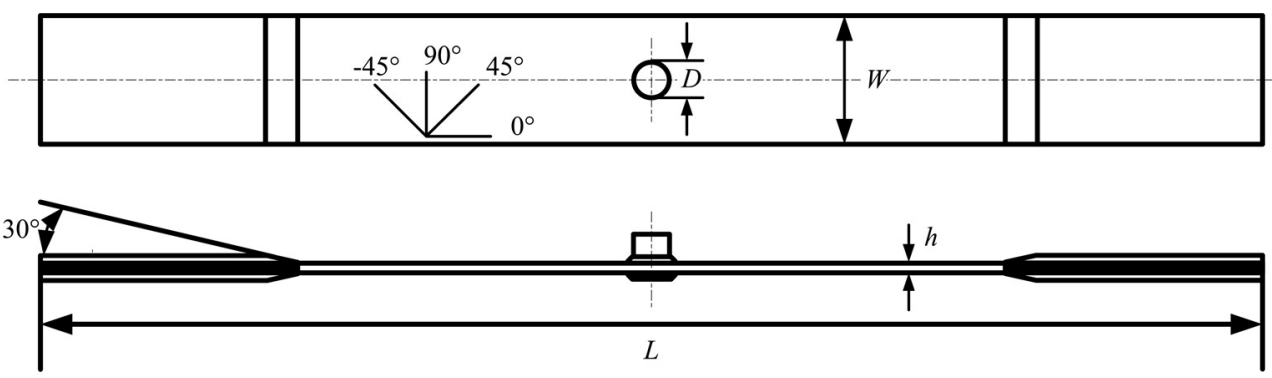

Fig. 1. Geometry of a composite laminate specimen containing a circular filled hole.

Experimental. In this section, uniaxial tensile experiments of balanced symmetric laminates are performed to examine the tensile strength of composite laminates with a central circular hole of $6.35 \mathrm{~mm}$ diameter. The issues of practical interest, such as the washer thickness efffect of the tensile strength, are addressed. The specimen preparation and material properties are described below. 
Specimen Preparation and Testing. The laminate plate contained sixteen plies of identical orthotropic material with the stacking sequence $\left[-45^{\circ} / 0^{\circ} / 45^{\circ} / 90^{\circ} /-45^{\circ} / 0^{\circ} / 45^{\circ} / 0^{\circ}\right]_{S}$. The number in the stacking sequence indicates the in-plane rotation angle of each ply relative to the reference $0^{\circ}$ ply (coinciding with the fiber direction). The nominal plate thickness $h$ equals to $2 \mathrm{~mm}$. The ply thickness is nominally $0.125 \mathrm{~mm}$. The specimens contain $6.35 \mathrm{~mm}$ diameter holes and are $38 \mathrm{~mm}$ wide and $250 \mathrm{~mm}$ long. A $3 \mathrm{~mm}$ thick washer is inserted between the composite laminates and the raised head bolt. Alternatively, nut washers of 2 and $3 \mathrm{~mm}$ thickness were used. A uniform clamping pressure is transferred to the composite through these washers. The in-plane geometry of these washers is $20 \times 20 \mathrm{~mm}$. The total washer surfaces are flattened, in order to ensure the maximum contact of the washer surface to composite plates.

Both open- and filled-hole tensile loading tests were performed until the full failure occured. The head travel and load on the specimen were recorded during the test. The test machine wedge grips had the same width as the specimen, as shown in Fig. 1. The tensile strength is presented in terms of the gross-area strength.

Experimental Results. To determine the failure load of structure details static tensile tests were carried out firstly, which could be used as the basic reference data for determination of the maximum load under the cyclic loading conditions. The net stress and strain distributions were obtained based on the strain measurements of the quasistatic test.

Table 1 shows the experimental results on static strength of filled hole laminates, where the gross and net cross-sectional areas are equal to $W h$ and $(W-D) h$, respectively. A typical fracture morphology of specimens with a filled hole is characterized by the nonuniform fracture patterns due to the existence of $\pm 45^{\circ}$ plies in the composite laminates.

$\mathrm{T}$ a b 1 e 1

Static Strength of Filled-Hole Composite Laminates

\begin{tabular}{|c|c|c|c|}
\hline Specimen & $\begin{array}{c}\text { Failure load } \\
P_{b}, \mathrm{~N}\end{array}$ & $\begin{array}{c}\text { Gross tensile strength } \\
\sigma_{b 1}, \mathrm{MPa}\end{array}$ & $\begin{array}{c}\text { Net tensile strength } \\
\sigma_{b 2}, \mathrm{MPa}\end{array}$ \\
\hline 1 & 38.1 & 501.7 & 602.5 \\
\hline 2 & 40.8 & 537.1 & 645.0 \\
\hline 3 & 41.0 & 539.6 & 647.9 \\
\hline 4 & 39.6 & 521.9 & 626.8 \\
\hline 5 & 40.4 & 532.3 & 639.2 \\
\hline
\end{tabular}

Comparison of statistical strength values of open- and filled-hole laminates is given in Table 2, where the mean values are calculated from 5 valid experimental data with the coefficient of variation $C_{V}=0.03$. The corresponding strain values are calculated by using the linear elastic theory with the tensile modulus of $70.5 \mathrm{GPa}$.

It is obvious that the existence of a filled hole would strongly reduce the static strength of the laminates. In contrast, the threshold value for the filled hole laminate is not much different from that of laminates without holes.

In case of a relatively high ratio of the maximum cycle load and the static failure load, the laminates can endure more than $10^{6}$ tension-tension cycles before fracture. Therefore, the effect of damage, such as filled hole, on the fatigue life of studied laminates is not significant. However, the static strength is strongly dependent on the damage situation. In this case, the fatigue strength can be assumed to be a certain share of the static strength, such as $80 \%$, and no additional fatigue tests are performed.

High durability for a high ratio of the maximum cycle load and the static failure load will lead to some difficulties in the determination of load levels since much larger fatigue 
$\mathrm{T}$ a $\mathrm{b} 1$ e 2

Comparison of Strength Values for Defect-Free and Filled-Hole Laminates

\begin{tabular}{|c|c|c|c|c|c|c|}
\hline \multicolumn{3}{|c|}{ Specimen } & \multicolumn{2}{|c|}{ Static strength } & \multicolumn{2}{|c|}{$\begin{array}{c}\text { Threshold value } \\
\text { for } 10^{6} \text { cycles }(R=0.1)\end{array}$} \\
\hline & & & Mean value & B-basis value & Mean value & B-basis value \\
\hline \multirow{2}{*}{\multicolumn{2}{|c|}{ No hole }} & Failure stress, $\mathrm{MPa}$ & 866 & 845 & 485 & 446 \\
\hline & & Failure strain $\mu \varepsilon$ & 12284 & 11980 & 6884 & 6324 \\
\hline \multirow{4}{*}{$\begin{array}{c}\text { Filled } \\
\text { hole }\end{array}$} & \multirow{2}{*}{$\begin{array}{l}\text { Gross } \\
\text { section }\end{array}$} & Failure stress, $\mathrm{MPa}$ & 526 & 474 & 445 & 433 \\
\hline & & Failure strain $\mu \varepsilon$ & 7468 & 6722 & 6316 & 6144 \\
\hline & \multirow{2}{*}{$\begin{array}{l}\text { Net } \\
\text { section }\end{array}$} & Failure stress, $\mathrm{MPa}$ & 632 & 569 & 534 & 520 \\
\hline & & Failure strain $\mu \varepsilon$ & 8969 & 8074 & 7574 & 7376 \\
\hline
\end{tabular}

life scatter will be induced by the given static strength scatter. The clamping pressure of the hi-lock bolt will also exert effects on the fatigue life of filled-hole laminates, which implies a higher scatter of the fatigue life data.

Based on the experiments, it is found that the inserted washers have the most significant effect on the tensile strength of filled-hole laminates. These effects can be subdivided into the following four categories.

1. The static tensile strength is sensitive to the thickness of washers. The experimental data show that, in presence of washers on both side of laminates, the mean values of failure load and the gross cross-sectional static tensile strength are $40 \mathrm{kN}$ and $526.5 \mathrm{MPa}$, respectively. In comparison, in presence of nut washers only, the failure load and tensile strength are reduced remarkably, as shown in Table 3.

$\mathrm{T}$ a b 1 e 3

Static Strength of Filled-Hole Composite Laminates with Nut Washers Only

\begin{tabular}{|c|c|c|}
\hline Specimen & $\begin{array}{c}\text { Failure load } \\
P_{b}, \mathrm{~N}\end{array}$ & $\begin{array}{c}\text { Gross tensile strength } \\
\sigma_{b 1}, \mathrm{MPa}\end{array}$ \\
\hline 1 & 34.0 & 447.8 \\
\hline 2 & 32.7 & 430.7 \\
\hline 3 & 32.5 & 427.6 \\
\hline Mean value & 33.1 & 435.4 \\
\hline
\end{tabular}

2. The experimental results show that after about ten thousands of cycles delaminations will appear at the interface of $45^{\circ} / 90^{\circ}$ or $90^{\circ} 90 /-45^{\circ}$ plies, which originate from the specimen edges and propagate towards the specimen center until approaching the washers. Since half of the width is pressurized by the washers, delaminations would be delayed and the fatigue life would be significantly increased.

3. Due to the relatively high clamping pressure, friction between the washers and the composite laminates is increased, which aggravates the temperature rise. In the experiments, the maximum temperature was controlled to be less than $40^{\circ} \mathrm{C}$, for which purpose the test frequency was reduced.

4. Higher values of the clamping pressure and friction leads to obvious abrasion of the composite laminates, manifested by the appearance of a bright wear surface with debris consisting of small amounts of carbon powders. 
Conclusions. The tensile strength of composite laminates with open and filled holes is investigated experimentally in this work. Based on the experimental results, the following conclusions can be made:

1. The static tensile strength of composite laminates may be reduced remarkably by pre-existing defects. However, in contrast, under the investigated loading conditions the fatigue threshold value is comparable for both types of damaged laminates.

2. In case of filled-hole laminates, both static and fatigue tensile strength values of studied laminates are sensitive to the presence and thickness values of the inserted washers. The experimental results indicate that application of thick washers between the laminates and the hi-lock bolt improves the static strength and fatigue life of filled-hole laminates.

3. Delaminations are mostly observed near the stress concentration zone of the hole region, whereas their number decreases with increase in the applied load and with the number of loading cycles.

4. Washer-induced clamping pressure and friction are two critical factors, which control the tensile strength of composite laminates.

Acknowledgments. This work is supported by the State 973 Program of China (2013CB035700), and the National Natural Science Foundation of China (11272259, 11002104 , and 11021202).

\section{Резюме}

Експериментально досліджено вплив сили затиску, тертя і розміру шайби на статичні характеристики шаруватих композитів із наскрізними і болтовими отворами. Проведено порівняння статичної границі міцності при розтязі і характера руйнування шаруватих композитів із наскрізними і болтовими отворами. Результати експериментальних досліджень показали, що на статичну границю міцності при розтязі шаруватих композитів впливає початкове пошкодження незалежно від наявності наскрізного чи болтового отвору. Порівняльний аналіз результатів досліджень зразків із наскрізними і болтовими отворами підтвердив той факт, що вид отвору (наскрізне чи болтове) незначно впливає на міцність від утомленості при розтязі досліджуваних шаруватих композитів. Установлено, що такі чинники, як розмір шайби, сила затиску болта і сила тертя, суттєво впливають на границю міцності при розтязі шаруватих композитів із наскрізним чи болтовим отвором. Використання стовщених шайб між шаруватим матеріалом і болтом-заклепкою значно збільшує статичну міцність і довговічність шаруватих композитів із болтовими отворами.

1. A. Öndürücü, Ü. Esendemir, and R. F. Tunay, "Progressive failure analysis of glass-epoxy laminated composite pinned-joints," Mater. Design, 36, 617-625 (2012).

2. A. J. Sawicki and P. J. Minguet, "Failure mechanisms in compression-loaded composite laminates containing open and filled holes," J. Reinf. Plast. Compos., 18, No. 18, 1708-1728 (1999).

3. I. Eriksson and C. G. Aronsson, "Strength of tensile loaded graphite/epoxy laminates containing cracks, open and filled holes," J. Compos. Mater., 24, No. 5, 456-482 (1990).

4. E. V. Iarve, D. Mollenhauer, and R. Kim, "Theoretical and experimental investigation of stress redistribution in open hole composite laminates due to damage accumulation," Composites Part A, 36, No. 2, 163-171 (2005).

5. P. Berbinau, C. Filiou, and C. Soutis, "Stress and failure analysis of composite laminates with an inclusion under multiaxial compression-tension loading," Appl. Compos. Mater., 8, No. 5, 307-326 (2001). 
6. B. Castanie, S. Creze, J. J. Barrau, et al., "Experimental analysis of failures in filled hole compression tests of carbon/epoxy laminate," Compos. Struct., 92, No. 5, 1192-1199 (2010).

7. P. P. Camanho and F. L. Matthews, "Stress analysis and strength prediction of mechanically fastened joints in FRP: a review," Composites Part A, 28, No. 6, 529-547 (1997).

8. S. D. Thoppul, J. Finegan, and R. F. Gibson, "Mechanics of mechanically fastened joints in polymer-matrix composite structures - a review," Compos. Sci. Technol., 69, No. 3-4, 301-329 (2009).

9. B. Yang, E. Pan, and F. G. Yuan, "Three-dimensional stress analyses in composite laminates with an elastically pinned hole," Int. J. Solids Struct., 40, No. 8, 2017-2035 (2003).

10. M. L. Dano, G. Gendron, and A. Picard, "Stress and failure analysis of mechanically fastened joints in composite laminates," Compos. Struct., 50, No. 3, 287-296 (2000).

11. U. A. Khashaba, H. E. M. Sallam, A. E. Al-Shorbagy, and M. A. Seif, "Effect of washer size and tightening torque on the performance of bolted joints in composite structures," Compos. Struct., 73, No. 3, 310-317 (2006).

12. Y. Yan, W. D. Wen, F. K. Chang, and P. Shyprykevich, "Experimental study on clamping effects on the tensile strength of composite plates with a bolt-filled hole," Composites Part A, 30, No. 10, 1215-1229 (1999).

13. U. Graham, M. R. Wisnom, and J. P. H. Webber, "A novel finite element investigation of the effects of washer friction in composite plates with bolt-filled holes," Compos. Struct., 29, No. 3, 329-339 (1994).

Received 22. 11. 2013 